\title{
ERDŐSI FERENC: KELET-EURÓPA ORSZÁGAINAK VÍZI KÖZLEKEDÉSE
}

(MTA Regionális Kutatások Központja, Pécs, 2008. 459 o.)

\section{KOROMPAI GÁBOR}

A könyv 3/5-e ugyan a tengeri közlekedésröl szól, de a terjedelmi aránytalanságot indokolja, hogy miközben a belvízi hajózás világméretekben veszít a jelentőségéböl, a tengeri szállítás a globalizáció eszközeként és egyben „termékeként” folyamatosan növeli a pozícióját.

A könyv egészére vonatkozóan a Szerző érdeme, hogy vállalta a számtalan kötöttség és az ebből fakadó sajátos tárgyalás, megközelítés nehezen leküzdhető nehézségét. Ez abból a rendkívüli állapotból fakadt, amit a sok országot érintő téma kikerülhetetlenül magával hozott. Módszertanilag ugyan elvileg joggal elvárható az egyveretüség, azonban a forrásadatok hézagossága és részben megbízhatatlansága miatt ezen elv tekintetében elkerülhetetlenné vált a kompromisszumos/áthidaló megoldás egészen a többféle ismereten alapuló józan becslésig. Igen gyakran találunk utalást a források pontatlanságaira, amikor azután a Szerző volt kénytelen a valószínü igazság felé terelni az olvasó figyelmét (pl. 162., 171., 327., 334., 364., $383 \ldots$ oldalak). Hiányoljuk viszont a nagyszámú szakmai fogalom (TEU, Dwt, LPG, Cgt, OBO, RO-RO, feeder, PEN IV, CIF...) feloldásának elmulasztását, valamint azt is, hogy a kötet sem fényképeket, sem táblázat- és ábrajegyzéket nem tartalmaz a kötet.

Miután egyszemélyes munkáról van szó, a feldolgozandó hatalmas anyagon csak önkorlátozó fegyelemmel lehetett úrrá lenni.

Következetesen megjelenik minden kérdésnél az általános bevezetö, majd a jelen és a várható jövő ábrázolásában a hajók mozgását és kikötését befolyásoló földrajzi adottságok pontos számbavétele. Tulajdonképpen ez adja a nagyterjedelmü munka összefogó, irányító gondolatait, meggyőzően átvezetve a következő vizsgálandó területekre.

A könyv első része a belvizi, a második része a tengeri közlekedést öleli fel. Mindkét rész e közlekedési alágazatok általános jellemzőinek vázolásával indul. Ezek az összefoglaló, a hajózási módok rendszertulajdonságait bemutató szintetizáló fejezetek szakmai újdonságok. (Ebben a tárgykörben majd csak akkor lehet ismét nagyot lépni, ha Európa egységes elveket érvényesít megfelelö statisztikák kibocsátásában is.) Ezt követi a Kelet-Európa nagy vízi út rendszereinek és országainak közlekedéséról szóló öt nagy fejezet - számos alfejezetre tagoltan. Ezek bemutatják a tárgyalt nagy vízi utak, az Elba, Odera, Visztula, Duna adottságait, forgalmuk alakulását, területi kapcsolatát. 
Tér és Társadalom 23. évf. 2009/1. 219-238. p.

Magyar nyelven korábban nem voltak olvashatók ilyen igényủ és részletességü elemzések sem a kelet-közép-európai, sem az orosz/szovjet birodalmi vízi út rendszerekről, azok területi-gazdasági szerepéről. Az alfejezetekből a jelen és a jövő tervei, lehetőségei gazdagon kifejtve tárulnak az olvasó elé.

A dunai vízi út tárgyalásánál szó van annak befejezetlenségéről és a magyar tengernélküliségből adódó kitörési kísérletről, a Duna-tengerhajózásról. Kiderül helyzetünk súlyossága, mert mind a vízépítésben, mind a hajógyártásban, kikötőfejlesztésben lemaradtunk a környező országok mögött. Már nem építünk folyamtengerjárókat és (pl. Szlovákiával, Csehországgal, Svájccal ellentétben) nincs egyetlen tengeri hajónk sem.

A könyv második része a tengerhajózásról szól, ugyancsak az általános jellemzők összefoglalásával, a kelet-európai sajátosságok kiemelésével, a térség globális tengerhajózásban betöltött szerepének értékelésével. Ezt követi hat fejezetben az egyes országok tengerhajózási vonatkozású természeti viszonyainak értékelése, a kikötöés hajóállomány mennyiségi és minőségi jellemzőinek bemutatása, a számos tényező által befolyásolt forgalom idỏ- és térbeli alakulása, a fejlesztési tervek vázolása.

Mind a belvízi, mind a tengerhajózási résznél vitatható a szibériai terület értékelése, de talán az orosz birodalom kiterjedése miatt elfogadható.

A Szovjetunió szétesését követő visszaesés után az utódállamok felismerték a tömegáruk, újabban pedig az értékesebb áruféleségek vízi szállításának jelentőségét és a megújulást, a hatékonyságot elősegítő privatizációban rejlő lehetőségeket. Ahol az olaj- és földgázvezetékek kifutnak a tengerpartokra, ott szakadatlanul folyik a kikötők bővítése, müszaki fejlesztése, az egymásra utaltságból adódó kooperáció. $\mathrm{E}$ múveletekről és várható gazdasági hatásaikról, valamint az európai szinthez felzárkózásra törekvő konténerizációról részletes ismeretekre tehet szert az olvasó.

A kötet haszna a széles horizontú kitekintésben jelölhető meg. Bőséges táblázataival és szerényebb számban szerkesztett ábráival szemléltetve bemutatja a vízi közlekedési területi kapcsolatok rendszerét, miközben egyértelmủvé teszi a hajókkal való szállítás előnyeit a többi szállítási móddal szemben, ha van jól kiépített folyamiés tengeri vízi út (megközelítési lehetőség), kellő számú és felszereltségủ kikötő, ha jól szervezettek és modern flottával ellátottak a hajózási társaságok. A gazdag, sok újdonságot tartalmazó szakmai ismeretanyaggal való megismerkedés jól jöhet a szakmabeli érdeklődőknek. A magyar vízügyben, folyamhajózásban, külkereskedelemben, felsőoktatásban tevékenykedő szakembereink igen hasznos, földrajzi ismereteket gazdagon tartalmazó szakkönyvhöz jutnak Erdősi professzor írásával, amit örömmel üdvözölhet minden további érdeklődő is. 